\title{
Dayah Cleric Views towards Aceh Community Plurality
}

\author{
Syarifuddin Abee ${ }^{1}$, Hasan Bakti Nasution ${ }^{2}$, Syahrizal Abas ${ }^{2}$ \\ ${ }^{1}$ Ph.D Student in State Islamic University of North Sumatera (UINSU), Medan, Indonesia \\ ${ }^{2}$ Lecturer in State Islamic University of North Sumatera (UINSU), Medan, Indonesia \\ syarif_psp@yahoo.com
}

\begin{abstract}
Aceh Province is known as the Serambi area of Mecca which is supported by the strengthening of complete Islamic values. The socio-religious aspects such as the character of society and religious institutions in Aceh have made the Islamic spirit become a historical and cultural awareness for the people of Aceh. This is the case with the position of the Aceh government which cannot be far from the legitimacy of Islamic law. This situation creates that Aceh must do within the framework of Islamic Sharia principles. As global development, Aceh is faced with the demands of community life related to plurality. So it's interesting to explore how the development of plurality discourse. Plurality is an objective reality in the community of humankind, even it becomes the law of God or known as sunnatullah, so it can be understood that humans in life are different from each other even human paths also vary in religion. Circumstances like this, encourage researchers to find out how the views of Islamic dayah scholars in responding to the ideas and development of the plurality of Acehnese society. This becomes interesting because the cleric and dayah (zawiyah) are two inseparable things, because on one side of the dayah as an institution of community religious strengthening that is filled by the thoughts of the cleric when creating social events. The study was investigated using a combination of theories developed by various theories of religious phenomena and then the researchers made it as a foundation for the mind in discovering the views of Aceh's natural dayah when responding to the phenomenon of plurality. So this research uses the field research method with an interview approach to dayah scholars in Aceh. thus, this study found the result that plurality in the view of Acehnese scholars that plurality in the context of humanity is sunatullah, and plurality does not mean equating religion and believing in many gods.
\end{abstract}

Keywords: Al Quran; Dayah ulema; plurality; Acehnese people.

\section{Introduction}

In modern society, shifts in values often occur, causing very sharp social changes between people. Material values or material values are highly respected and praised in human eyes. This material value is considered the most important so that it defeats other values such as human values, compassion, honesty, justice, truth, and respect and so on. The things that are considered modern are not only at the level of material but also things that are like thoughts such as problems in society, especially about plurality.

Plurality becomes a part of life, then influences the lives of some Acehnese people and sometimes even makes a reason in responding to a problem, for other communities plurality and even issues related to plurality seem to be a stumbling block in life, so that it is considered as a nuisance or even destroyer against religious values. Acehnese society with the latest developments, the presence of matters relating to plurality, such as differences in views about who has the right to bear as a cleric, differences in schools of society, differences in terms of thought, differences in terms of worship practices, differences in organization, tolerance and so.

These issues are interesting to study, especially since the people of Aceh are known as plural and have a pluralistic and even well-known culture. Deeply respect pluralism. 
Theoretically, pluralism itself contains two potentials, namely conflict and disintegration. However, a pluralistic society can also be seen as a source of dynamic change and progress. Furthermore, these two potentials depend on the community in responding to them, whether it leads to potential conflicts or will lead to a dynamic. ${ }^{1}$

However, it cannot be denied, in real life that the people of Aceh have become a plural society, thus plurality is a necessity, and so it must be responded positively. A society that respects and understands plurality is a society that understands the existence of sunnatullah, and sunnatullah is a provision of Allah that must be lived by every creature in the world. Compound society is a society that has diverse cultures and aspirations, but they always have the same position, there is no superiority between one tribe, ethnicity, or social group with another, have the same right to participate in a social and political life. Sometimes these differences can also lead to conflict, therefore, as an effort to overcome this problem, the concept or understanding of religious plurality and plurality is raised.

Acehnese people in their lives are people who respect differences and understand them as a reality of life, which is a potential awareness in respecting the plurality of shared life. If this potential can be responded to by the community with kindness it will become a force in shaping the culture of the community as awareness in building society. Aceh as one of the provinces in Indonesia that upholds diversity, which consists of several ethnic groups, religious and cultural background is a necessity of pluralism, this reality must be developed as a potential while anticipating that diversity can be fostered well and not be a reason to cause divisions.

Plurality is an objective reality in the community of humankind, even it becomes the law of God or known as sunnatullah, so it can be understood that humans in life are different from each other even the way humans also differ in religion. In the Qur'an, Allah explains, "For each of you (humanity) we have established the law (shari'ah) and the way of life (minhaj). If Allah wills, then surely Allah made you all a single people. But God made all of you concerning the things that He has given you. Then you are competing in goodness. To Allah is the place to return, then Allah will explain to you all about the problems that you have disputed."

\section{Review of Literature}

\subsection{The Concept of Cleric}

The term "cleric" is etymologically derived from Arabic which has been absorbed into Malay through a vocabulary mechanism that the term "cleric" comes from the word "alimaya 'lamu- 'ilman, the basic meaning is 'arafa which means knowing, one who knows is called" aalimun, plural of the word 'alima is' cleric. Furthermore, people who are very knowledgeable in Arabic are called al-amahallamah. Someone can be said as 'alim or' aliim if someone knows a lot. While the words' al'allamah indicate to very knowing, from the words 'alima which means knowing.

Cleric mean a person who is an expert in science, or an expert in science, or can also be called a scientist. According to Taufik Abdullah, the use of the word 'cleric' in Indonesia has shifted slightly from the original understanding in Arabic. In Indonesia, alim is interpreted as

\footnotetext{
${ }^{1}$ M. Dawam Rahardjo, Merayakan Kemajemukan Kebebasan dan Kebangsaan, (Jakarta: Kencana Prenada Media Group, 2010), p. 238.
} 
someone who has honesty and doesn't say much. In general terms, cleric have the meaning of being smart, prominent or people who are respected from religious circles, especially in terms of science. As a religious elite the term cleric is associated with Islam, this can be understood because the origin of the word cleric itself comes from Arabic which is then often identified with Islam.

\subsection{Aceh Cleric}

Kamaruzzaman and Hasbi, before explaining the typology cleric in Aceh, in their research first grouped Acehnese scholars into three groups, namely; first, the so-called senior scholars. This senior cleric was considered to be very charismatic and this cleric was also at some point in Aceh, often a place to consult leaders and community leaders. This senior cleric is often invited to Banda Aceh, even very active in playing his role, being a counterweight, giving his views on the problems that are happening and faced by the leaders and the people of Aceh and always giving his views on the Aceh government in carrying out the wheels of government in accordance with Islamic teachings .

Second, scholars who do not want to think about anything that happens in social and political life in Aceh. For these scholars, the involvement of cleric in social and political life cannot be separated from economic interests. Therefore, they are often apathetic about the situation of the Aceh government. This scholar, besides having bad experiences during the conflict that plagued Aceh, also felt there was no benefit at all in approaching the rulers in Aceh and this apathy then formed a character that was quite critical of the government. The consequence of this attitude is that they are not involved, including not having been asked for opinions, thoughts and considerations of each Aceh government as the holder of power in dealing with a problem. This cleric was more interested in only taking care of his dayah rather than engaging in practical politics, furthermore this cleric was more likely to be personally opposed to the government.

Third, the cleric who is looking for ways to make their dayah survive and utilize every pathway to the circle of power, so that the educational institution they lead always receives attention and assistance from the government. Those who belong to this group always try to find ways to be able to play their roles and functions as befitting the relationship between religion and the state, must be united, not even separated, so that the cleric of this group are always invited by the government to consult. The clerics of this group are considered to be in agreement with the path desired by the regional government and even these scholars often become mediators of interests from outside the power to within the power.

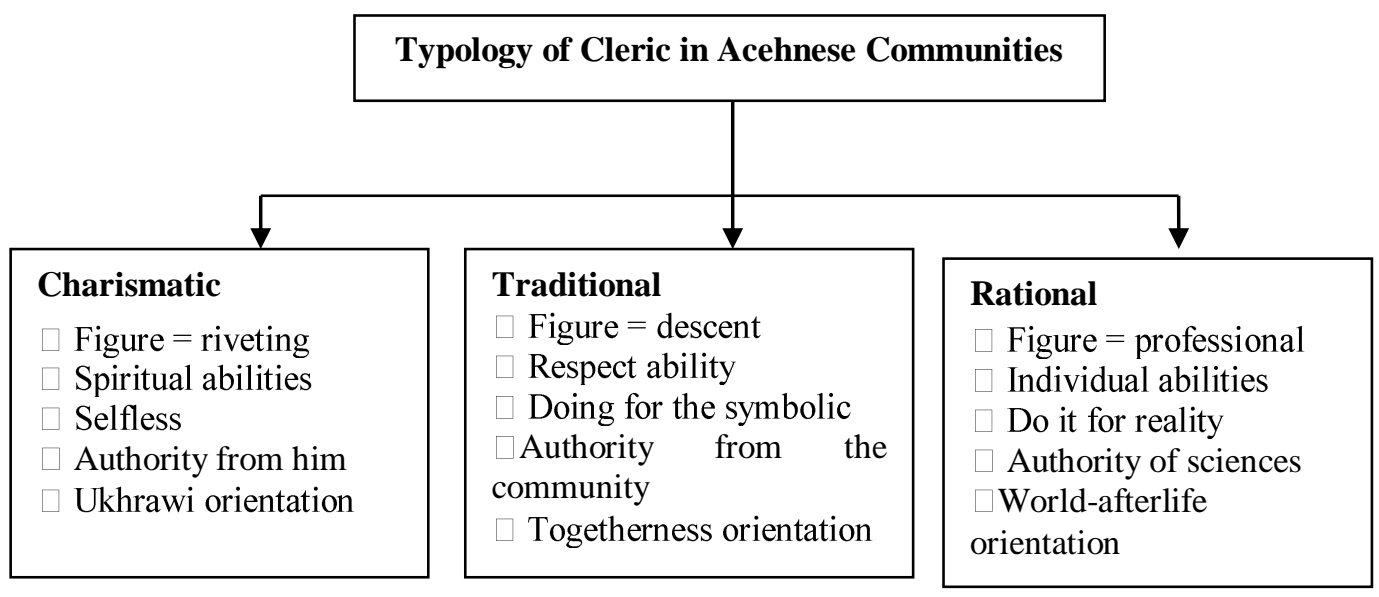




\subsection{Definition of Plurality}

Plurality is a sunnatullah that cannot be denied by anyone, even a certainty. ${ }^{2}$ That is, humans who inhabit this earth must have different religions, diverse ethnicities and cultures, as well as the sexes of men and women. Some of this plurality is naturally carried from birth, such as skin color, gender, and ethnicity. While other differences are socio-cultural, such as language, religion, ideology, perception and so on. Compound society is a society that has a diverse culture but is of equal and equal status. There is no superiority between one tribe, ethnicity, other social groups and even have the same right to participate in social and political life. However, these differences gave birth to conflict and the result of this conflict was then born the concept of pluralism and plurality of religion.

Philosophically, plurality is built based on the principle of pluralism, which is in the form of attitude, understanding and awareness of the reality of diversity, diversity as a necessity, as well as actively participating in giving meaning to its significance in the context of fostering and embodiment of life as a nation, a humane and dignified nation. M.Amin Abdullah equates plurality with diversity. Plurality is an objective condition that exists in a society, in which there are a number of groups or groups that differ from each other, whether in the form of economic strata, ideology, religious faith, or in the form of ethnic background.

\subsection{Pluralism}

Pluralism comes from English, pluralism. When referring to the English Wikipedia, as quoted by Imam Subkhan, is; "in the special sciences, pluralism is a framework of interaction in which groups show sufficient respect and tolerance of each other, that they fruitfuly coexist and interact without conflict or assimilation". An interaction framework in which each group displays respect and tolerance for each other, interacting without conflict or assimilation (assimilation / refraction). According to Ngainun Naim and Achmad Sauqi, in language, pluralism comes from the word pluralism which means plural or more than one. Whereas in terms, pluralism is not just a state or fact that is plural, plural or many. But more than that, pluralism is substantially manifested in the attitude of mutual recognition while respecting each other, respecting, caring for, even developing or enriching a plural, plural, and many circumstances.

According to Ali Masykur Musa, terminologically, pluralism can be interpreted as understanding (ism) or in the form of a value system that recognizes diversity or diversity, and in addition to the word pluralism, there is also the word plurality (plurality) which can be interpreted as "diversity". Dua kata ini, meskipun diderivasi dari akar kata yang sama, namun tetap tidak dapat dipertukarkan satu sama lainnya (interchangeable). Ketidaktepatan dalam memposisikan kata ini sesungguhnya menjadi sangat berbahaya. Sebagai contoh, untuk adanya kemajemukan agama, kata "pluralisme agama" (religious pluralism) sesungguhnya kurang tepat untuk digunakan.

The more appropriate word according to Ali Masykur Musa is religious plurality, because it places more emphasis on one's recognition of the diversity of religions in the world, while the term religious pluralism is suspected by many scholars, especially Muslim

\footnotetext{
${ }^{2}$ Masykuri Abdullah, "Pluralisme dan Toleransi", in Harian Kompas, 8 April 1999, p. 6.
} 
scholars, who reject the idea of religious equality. Religion, according to them, can have implications for one's religious beliefs. Understanding pluralism as such seems more likely to be persuasive so that it does not have implications for gaps in thought development.

\section{Discussion}

Regarding the Muslim movement in Aceh, it is not actually a sensitive issue, both moderate and non-Islamic, because Islam is respecting differences. But these differences must be within the Shari'a frame. Don't just come home from abroad and never read and understand the school's understanding, so don't talk about the prohibited religious prohibition. As was the case in the Sibreh village, Greater Aceh, Muhammadiyah was once there and now without frontal running a maulid and worship of tarawih 20 prayer, in essence by wrongly blaming for the common good and accepting each other.

Lem Faisal further explained that when viewed from ordinary people, although this was not used as the main benchmark, most people tended to consider groups other than the Shafi'i school to be forbidden. And it can be announced because this is the result of ordinary people's thinking. Personally, the diversity of the schools actually does not become a problem for the understanding of the upper classes, but friction in the school of thought occurs in the lower classes.

Lem Faisal hopes that those who develop plurality issues must be able to find a language that is in line with local wisdom. Don't develop pagan language or the language of someone who is considered bad for the community.

Lem Faisal, the current group or the new generation is a proud and arrogant generation that blames past generations, even though this is not the case, this new generation should be more wises. In the context of respecting differences is a sunatullah. The one that must be conveyed to the community is mutual respect for differences within the school of thought. And one united force is united understanding, for example Europe is united with plural understanding and they cannot be tampered with. And so it is with Iran, which is a Shia school. America and Iran are noisy because of the imposition of a school of thought, and so is the case with Sunni and Shi'a today. The issue of unity can be seen from the problem of applying Islamic law in Brunei Darussalam which cannot be contested by anyone and any country.

In the context of the differences of the current school, actually it can still be answered by the methods of jurisprudence in the arba'ah school. And if there is no solution in the Shafi'i school. Then a new ijmak is done again. Regarding the existence of the cleric Consultative Council (MPU), according to Lem Faisal there are three authorities. First, issuing legal edicts. Second, recommend the rules to the government. And third, cleric regenerate. In connection with the MPU results, by Lem Faisal in an effort to stem the issue of plurality that must be done is to encourage and provide criteria for the heresy that is developing in Aceh so that the friction of plurality in Aceh is not too developed. And all of these policies have been accepted by the executive and legislative branches. And all MPU fatwa have been well received by the people of Aceh. And the MPU fatwa will only come out if it is in an urgent condition, if not, it will be limited to merely persuasive

Related to obstacles in handling religious issues in Aceh, it is closely related to political issues that enter the religious realm. Because in politics do not see right from wrong. Because in politics only wants support. The biggest challenge is political issues that play religious issues. For example, politics related to Aceh's post-peace support problem in the past. For 
solutions that encourage plurality issues, they must be able to design boarding school education institutions and general education institutions. So that various talks can be included in education. Because most people are born from educational institutions. Therefore, public education without religion makes a good contribution to the social system.

In the context of the most powerful school of thought in the Acehnese community is the Imam Syafi'i school, although in daily social activities there are those who practice the practices of other schools, such as the patch it up or others. Lem Paisal gave an example, as in our daily life in a coffee shop, everything that we have not paid for but we have already eaten. If in the Shafi'i school, we have already paid for it and it can be eaten. Such is the miniature model of the application of the school in Aceh. And all this is influenced by the pedigree of knowledge and in Aceh there is no science outside the Shafi'i school. Because in each region have their respective schools of pedigree.

In the context of the existence of other schools in Aceh and its relation to the case for the Beureunuen mosque for example. Lem Paisal stressed that friction between these schools tends to exist in the present, and not in the past. Because there are certain groups that use some Acehnese government actors. However, this pluralism problem, in Aceh began to be disturbed after the tsunami. The development of the school in Aceh consists of two groups, first, the lower middle class, which is still consistent with the belief in the school that it believes. and secondly, the middle class and above, no longer the experience of the school, because they already considered the practice of the school of religion to be in contact with scientific matters. Unlike the middle to lower, they are able to understand the practice and scientific.

Regarding the Al-quraan and plurality, Lem Faisal stressed that the Al-Quraan respects plurality, and even there are verses that state that humans were created with tribes and nations. Likewise the problem of worship, for example the problem of rubbing the head when wanting to perform prayer or performing ablution. In Hanafi only rubs the head as a whole and in Shafi'i only a part of it. And in its implementation, fiqh also touches plurality.

In the history of the development of this school tends to be influenced by the lineage of the school, for example, Nawawi, Rafi'i, Ibn Hajar which is centered on the lineage of Imam Shafi'i. For in Aceh, Acehnese scholars such as Shaykh in Kuala and Ar-Raniry have left the works that are used as role models for the people of Aceh and all are in line with the Shafi'ai school of thought. It is different from Hamzah Fansuri followers, who have a methodology that tends to be easily misleading, whereas Hamzah Fansuri's thoughts are not necessarily misleading. Hamzah Fansuri's thoughts are considered to be misleading by ordinary people. However, Hamzah Fansuri's study was understood in educated circles, such as doctoral candidates, so that was not a problem. So learning philosophy studies should not be understood by ordinary people.

The reason why certain dayah groups appear to be at odds with Abuya Amran Wali at this time is because they do not want Amran Wali's thoughts not to be conveyed to the general public. Therefore, give religious ideas according to their understanding and in accordance with the society at hand. On another matter, Lem Faisal exemplified the bathroom case of the Baiturrahman Raya mosque, Lem Faisal once protested the form of toilet rooms that urinate must be standing, so that in the context of urination the court caused disquiet for those who used it. According to Lem Faisal, for the dayah people keep the purity from splashes of urine by urinating while sitting or by preparing a toilet in accordance with the Shari'a. 
Another view related to the response of dayah scholars on the issue of plurality in Aceh, as responded by Teungku Sofyan who is one of the dayah scholars in Aceh, Sofyan explained that the issue of plurality tends to respond to sensitive matters. In general, Aceh does not cause disunity, but those things happen, and that also involves matters of worship. Plurality in Aceh is not in the case of non-Muslims, but rather in terms of worship, even differences among people themselves, which should not need to happen. ${ }^{3}$

Aceh nurtures non-Muslims even highly respect, especially in Aceh where there has never been any friction even though Aceh has already implemented Islamic law. Therefore, non-Muslims should not worry too much about applying Islamic Sharia law. Regarding the solution from MUNA circles, it is related to understanding heresy and schools of thought from Aceh, which is often held programs with tuengku and scholars of the dayah and some analysts from universities such as Hasbi Amiruddin and Iskandar Usman. Islam must be filled with a foundation of thought in order to create a situation of coolness in religion. Specifically among MUNA scholars, acknowledge differences and the development of science or continue to accommodate differences. This has been proven when working visits to Palembang and several other regions. In terms of the development of the school in Aceh, Sofyan argues that:

"It is known that in Aceh is a Shafi'i school. This is known from salafi dayahs. All dayahs in Aceh study the books that refer to the shar'i imam. But it still recognizes the other third school (School 4). The difference between schools of thought is not a problem in Aceh, it's just that Aceh only follows the Shafi'i's pattern of worship, the other schools are merely rewarding. And the government has set everything in legislation. Associated with the development of other schools are also being developed. This can be seen from several differences in the implementation of ibdah in Aceh. all of this must be in agreement and there needs to be a solution from the government" 4

According to Sofyan, the Al-quraan is as a guide, for Muslims and non-Muslims. Because Islam is a guide for all people. Islam is rahmatan lil'ālamīn. Plurality is regulated in the Al-Quran. Likewise with the concept of da'wah also regulated in the Al-quraan, not only the procedure of monotheism, but also the issue of war. And this is what is called plurality. Everything is arranged in the Al-quraan and this complex set of plurality. The Surah AlBaqirun is one of the verses that supports plurality. And the verse that explains tribes and knows each other. In terms of defining Pluralism, Sofyan clearly argues that plurality is freedom in having free opinions. Related to the relevance of the MUI decision, of course, already has an in-depth study that has been carefully considered.

Another view also emerged from Muhib's view that plurality must have limitations. The attitude of mutual diversity is plurality insofar as it can still be considered tolerant and reasonable. So that plurality is an assumption that considers religious practices freely through their respective thoughts, and then, plurality is different views in religion, or undergoing religious activities according to their respective teachings. ${ }^{5}$ Related to Islam and plurality Muhib explained that.

\footnotetext{
${ }^{3}$ The results of interviews with Sofyan

4 The results of interviews with Sofyan

5 The results of interviews with Muhib 
"Plurality is one of the legitimate aspects of Islam in Indonesia and is sacred and true, of course if indeed its plurality is still in the corridor. To the extent that it's okay, it doesn't matter"

In the statement above, it appears that some cleric in Aceh still view the issue of plurality as a dynamic issue in the sense that it is still easily infiltrated by streams that damage the unity of Islam. So when accepting the issues of plurality, ulemas in Aceh are still based on boundary values in Islamic teachings. In the context of interfaith plurality, Muhib declared as the movement of sunatullah, and when the existence of Islam was over and only Islam was recognized. In relation to community organization groups, there seem to be extreme symptoms due to the limited knowledge they have.

\section{Conclusion}

Based on the results of a study entitled the views of Islamic dayah scholars in Aceh in response to plurality that Aceh's cleric emphasized that the application of Islamic Islamic values in Aceh had plurality even though it was not called plurality. Because the discourse of plurality for the views of dayah cleric in Aceh is only a matter of the motives of the term, whereas the application of plurality or the substance of plurality has long been practiced by Islamic scholars. Related to issues that consider Acehnese dayah scholars to be intolerant and do not understand plurality are invalid discourses and tend to result in negative findings regarding these dayah scholars not through a comprehensive research process.

\section{References}

Abu al-Husain Ahmad bin Faris bin Zakaria al-Qazwini Ar-Razi. (2008). Maqāyis al-Lughah, Qahirah: Dār al-Hadis.

Abidin Nurdin. (2012). "Reposisi Peran Cleric dalam Penerapan Syariat Islam di Aceh", dalam Jurnal Al-Qalam, Vol. 18, Nomor 1, Januari-Juni

Ali Masykur Musa, (2014). Membumikan Islam Nusantara, Respon Islam Terhadap Isu-Isu Aktual, Jakarta: Serambi Ilmu Semesta.

Alwi Shihab. (1999). Islam Inklusif, Menuju Sikap Terbuka dalam Beragama Bandung: Mizan.

Amirulloh Syarbini. (2011). “Al-Qur'an dan Kerukunan Hidup Umat Beragama”, dalam AlQur'an dan Kerukunan Hidup Umat Beragama, Refleksi Cendekiawan Muslim Muda untuk Perdamaian Bangsa, Jakarta: PT Elex Media Komputindo.

Hasan Bakti Nasution. (2005). Filsafat Umum, Bandung: Citapustaka Media.

Ihsan M. Jakfar and Teuku Zulkhairi. (2016). Memperbaiki Orang Kuat Menguatkan Orang Baik, Pemikiran Tgk. H. Muhammad Yusuf A. Wahab dalam Membangun Umat, dari Pengetahuan Fardhu 'Ain hingga Pentingnya Politik Islam, Banda Aceh: Ibnunourhas,

Imam Subkhan. (2007). Hiruk Pikuk Wacana Pluralisme di Yogya, Yogyakarta: Kanisius.

Martin H. Manser. (1995). Oxford Learner Pocket Distionary, USA: Oxford University Press.

M. Amin Abdullah. (1996). Studi Agama, Normativitas atau Historisitas, Yogyakarta: Pustaka Pelajar.

Masykuri Abdullah. (1999). "Pluralisme dan Toleransi”, dalam Harian Kompas. 
Mukhlisuddin Ilyas. (2012). Pendidikan Dayah di Aceh Mulai Hilang Identitas Yogyakarta: Pale Indonesia Media.

M. Hasbi Amiruddin. (2014). Aceh: Syariat Islam, Politik, dan Pendidikan, Banda Aceh: ArRaniry Press.

M. Hasbi Amiruddin. (2002). "Cleric Dayah: Peran dan Responnya Terhadap Pembaruan Hukum Islam," dalam Dody S.Truna dan Ismatu Ropi (ed.), Pranata Islam Di Indonesia Jakarta: Logos Wacana Ilmu.

M. Dawam Rahardjo. (2010). Merayakan Kemajemukan Kebebasan dan Kebangsaan, Jakarta: Kencana Prenada Media Group.

Misri A. Muchsin. (2007). "Islam Menghargai Nilai-Nilai Kemanusiaan", dalam Hasan Basri dan Muhibuddin Hanafiah (ed.), Pencerahan Intelektual Referensi bagi Khatib, Penceramah, dan Da'i, (Banda Aceh, Badan Rehabilitasi dan Rekonstruksi (BRR) Aceh-Nias dengan Badan Komunikasi Pemuda Remaja Masjid Indonesia (BKPRMI) Nanggroe Aceh Darussalam.

Muhammad Suhaili Sufyan and Bhaharuddin bin Che Pa. (2013). Mengembalikan Peranan Cleric Sebagai Pengawal Moral Masyarakat Aceh, dalam Hukum, Moralitas dan Hak Asasi Manusia dalam Perspektif Islam, Prossiding Seminar Nasional Jurusan Syariah, Sekolah Tinggi Agama Islam Negeri (STAIN) Zawiyah Cot Kala, Langsa.

Muhammad Wahyuni Nafis. (2014). Cak Nur Sang Guru Bangsa, Biografi Pemikiran Prof. Dr. Nurcholish Madjid, Jakarta: Kompas Media Nusantara.

Muslim Ibrahim. (2013). Peranan Cleric dalam Pembangunan Aceh Pasca Gempa-Tsunami, Banda Aceh: Badan Arsip dan Perpustakaan Aceh.

Mohammad Iskandar, et.al. (2000). Peranan Elit Agama pada Masa Revolusi Kemerdekaan Jakarta: Depdikbud.

Ngainun Naim and Achmad Sauqi. (2008). Pendidikan Multikultural Konsep dan Aplikasi, (Yogyakarta: Ar-Ruzz Media.

Syahrizal Abbas. (2007). "Islam dan Kemajemukan", dalam Hasan Basri dan Muhibbudin Hanafian (ed.), Pencerahan Intelektual, Referensi bagi Khatib, Penceramah, dan Da'i, Banda Aceh: Badan Rehabilitasi dan Rekonstruksi (BRR) Aceh-Nias dan Badan Komunikasi Pemuda Remaja Masjid Indonesia (BKPRMI) Nanggroe Aceh Darussalam.

Plurality oleh John M. Echols and Hassan Shadily. (2003). mengartikan dengan 1) orang banyak; 2) perbedaan antara jumlah suara yang terbesar dan jumlah berikutnya; 3) jumlah terbanyak. Lihat: John M. Echols dan Hassan Shadily, Kamus Inggris Indonesia, cet. 27, Jakarta: Gramedia Pustaka Utama.

Yasmadi. (2005). Modernisasi Pesantren, Kritik Nurcholish Madjid terhadap Pendidikan Islam Tradisional, Jakarta: Quantum Teaching.

Taufik Abdullah, et. al. (1988). Manusia dan Kemelut Sejarah Jakarta: LP3ES.

Zakiyuddin Baidhawy. (2002). Ambivalensi Agama Konflik dan Kekerasan, Yogyakarta: LESFI. 